\title{
E-MARKETING AND ITS EFFECT ON CUSTOMER SATISFACTION IN THE COMMERCIAL BANKS - LIBYA
}

\author{
Ali Ismail Ali Algnaidi ${ }^{1}$, Arun Kumar Tarofder ${ }^{2}$, S. M Ferdous Azam ${ }^{1}$ \\ ${ }^{1}$ Post Graduate Centre, Management and Science University, University Drive, Off Persiaran Olahraga, 40100 Shah Alam, \\ Selangor; ${ }^{2}$ Faculty of Business Management and Professional Studies, Management and Science University, University Drive, \\ Off Persiaran Olahraga, 40100 Shah Alam, Selangor.
}

Corresponding Author: Ali Ismail Ali Algnaidi, email: ali.odac86@gmail.com

\begin{abstract}
The aim of this paper is to evaluate customer satisfaction in the banking sector of Libya, based on e-marketing. This is an empirical study using mainly primary data collected through a well-structured questionnaire. The study was conducted after validity and reliability testing of a self-administered questionnaire using SPSS program. The questionnaire was distributed to a sample of 150 bank customers in Misurata, Libya. This paper makes a useful contribution as there are only a few studies dealing with the assessment of components of e-marketing in banking sector of Libya. The findings showed that there is a significant relationship between the customer satisfaction and e-marketing. Based on three different independent variables (mobile phones, internet and credit cards), regression analysis showed that all these variables positively influenced customer satisfaction in Libyan banking sector. This research has greater implication for the bank management who are looking forward to newer business strategies to achieve customer satisfaction.
\end{abstract}

Keywords:

e-marketing, customer satisfaction, Libya, internet, mobile banking, credit cards

Article Received: 18 October 2020, Revised: 3 November 2020, Accepted: 24 December 2020

\section{Introduction}

Banks play an important role in the investment process and influence the development and management of the economy at the local, regional and global levels (Umer, Dahri, Raza, \& Qureshi, 2020). In addition, banks have become increasingly important in recent times due to the collapse of economic systems such as socialism (OforiBoateng, Amoh, \& Awunyo-Vitor, 2020). Towards a new global system that aims to transform the world into a small investment village, banking is one of the most important industry (Iranzadeh, Bafandeh Zendeh, Aali, \& Garepasha, 2020). Its impact is not limited to the level of the bank, but also on the impressions of the customers and the services offered by banks, which is one way to raise the competitiveness of the bank (Noman, Gee, \& Isa, 2017).

The marketing function is one of the most important administrative functions in the organization and is specific to its success (Sampaio, Perin, Dolci, Santini, \& Ladeira, 2019). The ability of any organization to produce goods and provide services is limited unless accompanied by an efficient marketing effort that helps to identify the customer's needs and increase the sales and profitability that the institution seeks to achieve (Osifo et al., 2019). The development of marketing activity in the banks over time, which led to a change in the philosophy and view of the management of the market, where this development has gone through many stages and the banking marketing occupies an important position in the administrative composition of the banking institution.

E-marketing has recently become the unchallenged marketing arm, although it is only a few years old but has enjoyed unprecedented popularity and popularity in most of the communities it has used and at all levels of society (Haddad, 2014). E- 
marketing is defined as a type of marketing for a particular product or service on the Internet (Faezy Razi \& Shahabi, 2019). E-marketing is the application of a wide range of information technology in order to achieve the restructuring of marketing strategies to increase customer benefits through effective market segmentation and effective electronic marketing mix that increases the efficiency of the commercial bank and builds good relationships with customers (Sandoval, Canada, Sánchez-Torres, \& Alzate, 2018). In addition, improving the Internet of banking services is a prerequisite for the sustainability of the banking system (Kato, 2019). The increasing interest in electronic banking services, both for the bank and the customer at the same time is an effective tool to achieve continuous improvement of all aspects of service operations, as the electronic services provided by banks enables their managements to know their competitive position in their environment and to start to upgrade these services by increasing their share (Sandhu \& Arora, 2018).

There are several ways of electronic marketing, these include, credit cards, internet, and mobile phone (Ramadan \& Aita, 2018). In this regard, this study focused on the role of electronic marketing of all kinds of banking services in Libyan commercial banks and the extent to which they achieved customer satisfaction, mainly to maintain the reputation of the bank, to win the trust of the customers on one hand and to keep abreast of the developments on the other. There is a paucity of research regarding customer satisfaction through electronic marketing in Libya, in spite of its importance to both the customer and the satisfaction of the service provided by the institution, and also the importance of the institution as increasing the trust of the client works to increased customer satisfaction and therefore repeated dealing, which affects the profitability of the organization (Gopalaswamy \& Nguyen, 2018). Previous literature has reported the slow pace of technological developments (Endara, Ali, \& Ab Yajid, 2019), which led to low customer satisfaction and the lack of awareness of some banks about the importance of the use of electronic trading system (Bhat, Darzi, \& Parrey, 2018). In addition, banks in Libya are new in terms of applying information technology in their banking services. A study (Abulgasem, Janicic, LecicCvetkovic, Kostic-Stankovic, \& Gligorijevic, 2013) determined that banks in Libya need to focus on improving the quality of banking services. Based on the above, this study aims to find out the effect of e-marketing (credit cards, internet, mobile phone) on customer's satisfaction in the Libyan commercial banks.

\section{Literature Review}

In spite of their service, commercial banks face the problem of customer satisfaction in many situations; inadequate personnel to attend clients, crowded telephone lines and minimal banking hours (Abdullah, 1996). This is especially valid in Libya, a developing nation where there is a lack of structure in the banking community (Ramadan \& Aita, 2018). Therefore, in order to gain customer satisfaction, Libyan financial institutions are expected to spend more resources and carry out study on direct banking facilities (Ahmadi Danyali, 2018). The biggest challenge confronted by Libyan banks is that most of them are now powered by obsolete systems (Ofori, Boateng, Okoe, \& Gvozdanovic, 2017). Another challenge is the shortage of professional and qualified workers, which essentially describes their consumers' lowquality service output (Ahmida Ali, 2011). Improving customer care can require training procedures or upgrades to the bank's computer information systems (Bapat, 2017). Although enhancing consumer experience may contribute to increased visible accounting expenses, the frequency of intangible costs may also be steered away (Susanto, Chang, \& Ha, 2016). Through studying consumer satisfaction, bankers will build quantitative data, with the hope of emphasising that the focus and quality of excellent customer satisfaction will contribute to enhanced sales that are greater than increased costs. 


\section{The Concept of E-marketing}

Electronic marketing is the process of establishing and maintaining customer relationships through online activities, in order to facilitate the exchange of ideas, products and services that achieve the goals of both parties (Sharif \& Butt, 2017). It is also known as: the use of the possibilities of the Internet, various communication networks and multimedia in achieving marketing objectives with the resulting new advantages and possibilities (Mishra \& Singh, 2015). E-banking aims to provide automatic delivery of traditional and new banking services directly to the customer through interactive electronic channels (Narteh, 2013a). These services include systems that enable customers of financial institutions, individuals or companies to access bank accounts or obtain information on financial products and services through the network, private, or public, including the Internet (MA, 2013). In this mode, the customer will not have to move to the bank if he can do the work he wants from his bank from anywhere (Narteh, 2013b). Any time "or that" the banks provide banking or innovative services or what is known through electronic networks, and access is limited to participants in accordance with the terms of membership determined by banks through one of the outlets on the network as a means of communication (Liébana-Cabanillas, RejónGuardia, \& Muñoz-Leiva, 2013).

\section{Role of Internet}

Through Internet, banks offer their services through one of the three types of websites, namely the information site, the interactive website and the reciprocal website, which differ in terms of the type service provided to customers (Amin, 2016). A study (Khrewesh, 2011) on adoption of e-banking services in Palestine showed that the Internet is one of the main factors influencing the adoption of electronic banking services in Palestine. Another study in Gaza (El Talla, Al Shobaki, \& Abu-Naser, 2019) reported that e-banking is a good and important way to attract customers and develop ecommerce in Palestine, and that its impact is limited to customers who are good at dealing with the Internet. Lack of fast and stable information networks that can transmit information in image and sound at the same time, speed and high Internet is a big challenge for developing countries (Wadi, 2007). A researcher in Libya (Katz et al., 2011) reported the lack of the necessary infrastructure for the processing of Internet sites, and the lack of administrative and human cadres with scientific qualifications and field experience, whether in terms of computer or language use and recommended training and qualifying IT professionals and systems in the banks.

\section{Credit Cards in e-banking}

Credit cards are used to pay the value of purchases and services provided by institutions to the holders of these cards (Shahrokhi, 2008). Credit cards are considered to be fairly safe for domestic and international use (Hogan \& Campbell, 2017). A study (Khizindar, Al-Azzam, \& Khanfar, 2015) in Saudi Arab discusses the advantages of the process of security and safety of the customer service electronically are reducing waiting time of the customer for service, reducing the operational cost of the bank, reducing the pressure on the bank's employees and serving the largest segment of customers. A study (Al-Ghaith, Sanzogni, \& Sandhu, 2010) on challenges faced by Islamic countries in using electronic commerce showed weakness in the telecommunication index, such as fixed and mobile telephone lines, the cost of communication and waiting times for telephone service. Another (Ehtisham-Ul-Mujeeb, Shakil Ahmad, \& Rashid, 2012) stressed the importance of spending on electronic commerce and information technology in Islamic countries to benefit from e-commerce applications by to allowing customers to use some of the e-services.

\section{Mobile Banking}

Mobile banking is a facility through which banks offer balance tracking services and other information SMS or smart phones, there are applications that allow customers to conduct their banking transactions through them if they are 
connected to the Internet (Delrose Noronha, 2017). A study (Momani \& Magatef, 2016) reported great interest of university youth in online purchasing and the impact of the Internet as a commercial channel on the decision making process for them. The main challenge being faced by the Libyan banks is that most of them have the outdated programs for operation (Al-Ghaith et al., 2010). Another problem is the lack of qualified and experienced skilled human resource which eventually, explains the low quality of service delivery to the customers (Ahmida, 2012). Customer satisfaction is an evaluation of the totality of the purchase situation relative to expectations (Endara et al., 2019). It is the result of marketing activity. It is necessary to move and enter the corridors of customer preferences for the purpose of detailing and providing the appropriate services for them (Liébana-Cabanillas et al., 2013). It is one of the most inexpensive and powerful methods at the same time (Rios \& Riquelme, 2010). It can be done in writing or over the phone, but it is better to be done through the web (Abu Naga, 2007). When customers are satisfied with the use of a specific service, they are more likely to repeat purchasing and attempting at trying out the service line extensions (East, 1997). Libya, a developing country, where the banking sector lacks infrastructure, the banking institutions are required to spend more efforts to retain customers and to carry out research to direct their banking services towards optimum customer satisfaction (Ramadan \& Aita, 2018).

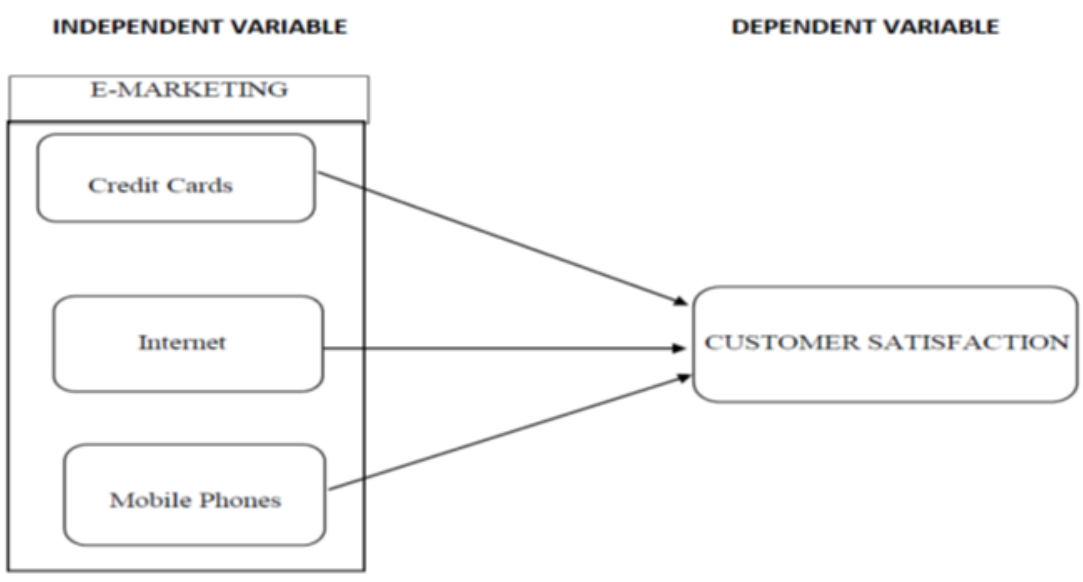

Figure 1 Conceptual Framework

\section{Methodology}

The researcher used the analytical descriptive method to conduct this study where the study population consisted of all the customers of the Libyan commercial banks in the city of Misurata. The sample of the study included the customers who were present at the time of distribution of the questionnaire. The sample of the study was selected using the random sampling method so that each customer who made transaction with commercial banks had equal opportunity to be selected as respondents. The data was collected from the customers who were receiving services from the top three commercial banks in the city of Misurata,
Libya. An official letter was acquired from the banks' management before collecting data from the bank customers. With their approval, data was collected directly from the respondents who gave consent. Out of 200 distributed questionnaires, 150 were answered.

The researchers chose the questionnaire, adopted from previous studies, as a tool for collecting the data needed for the field study. A pilot study was conducted to verify the validity of the questionnaire. The internal reliability was checked with Cronbach alpha which was above average (0.76). Respondents were given questionnaires which contained three sections or parts; Section 1 
included the initial data (personal) of the interviewees, Section 2 included the questions on the independent variables of the study. Section 3 was allocated to measure the dependent variable that is the satisfaction of customers The constructs of this survey were measured with a 5-point Likert scale, ranging from "strongly disagree" (1) to "strongly agree" (5). Data was processed in the SPSS program. In the current research, exploratory factor analyses and multiple regression analyses were carried out. A widely employed technique in social science analysis is multiple regression analyses. Usually the findings are viewed in this tool to demonstrate how many independent variables participate in defining a single dependent variable according to variance. The study currently includes three independent variables (credit cards, mobile phones and internet) which affect one dependent variable (customer satisfaction). This study fulfilled the prerequisites of Multiple Regression Analysis (MLR). Mean and Standard Deviation were used for descriptive statistics. ANOVA was used to measure the significance of bivariate between the independent and dependent variables, thus, achieving the objective of this study. Regression Analysis was used to determine the relationship between independent and dependent variables, the direction of the relationship, the degree and strength of the relationship.

\section{Data Analysis and Discussion}

The data was evaluated by the SPSS version 21 with a data size of $\mathrm{N}=150$. The mean age for the 150 customers was 25.74 with a standard deviation of 8.23. The gender distribution was considerably even whereby female respondents represented a little more than male respondents with $57.3 \%$ of the total respondents. Majority had an education level of Bachelor degree (80.1\%) and a monthly income between Libyan Dinar 200 to 1000 (89.7\%). The sample mean for the dependent variable, Consumer Satisfaction was 3.95 with a standard deviation of 0.73 .

\section{Table 1: Descriptive Statistics}

\begin{tabular}{lcc}
\hline Variable & Frequency & Percent \\
\hline Gender & 64 & \\
\hline Male & 86 & 42.7 \\
Female & & 57.3 \\
\hline Highest Degree & 120 & 80.1 \\
\hline Bachelor & 22 & 14.7 \\
\hline Master & 08 & 5.2 \\
\hline Doctorate & & \\
\hline $\begin{array}{l}\text { Monthly Income } \\
\text { LYD) }\end{array}$ & 04 & 2.7 \\
\hline$<200$ & 135 & 89.7 \\
\hline 200 to 1000 & 11 & 7.6 \\
\hline$>1000$ & & \\
\hline
\end{tabular}


Total

The Exploratory Factor Analysis (EFA) attempts to investigate the associations between the observed and latent variables. Factor loadings reflect the nature of the interaction between study factors and variables (Latent Variables). By obtaining the factors, the EFA offers details about the factors that better reflect the results. the rotated part matrix initial phase indicated objects that need to be removed due to cross loadings. It is proposed that variables with cross loads of 0.5 or greater could be omitted from the study for each component. EFA was carried out in the second round after removing the cross loadings of the component within various factors and the loading performance of the remaining factors is as follows. Table 3 displays the effects of the regression study. In this table, we have a regression coefficient that informs us how much variation is possible due to the change of one independent variable unit.
150

100.0
Next, we have values of t-statistics that inform us whether or not an independent variable has a significant influence on the dependent variable. Mobile phones (t statistics 3.199>1.96 at $\mathrm{df}=72$ ) and $\mathrm{p}=0.002<0.05)$. Internet ( $\mathrm{t}$ statistics 4.644> 1.96 at $\mathrm{df}=72$ ) and $\mathrm{p}=0.000<0.05$ ). Mobile phones and internet are significant to influence the customer satisfaction in commercial banks of Libya. Credit cards (t statistics $4.921>1.96$ at $\mathrm{df}$ $=72$ ) and $p=0.000<0.05)$ are also significant as $p$ value is less than 0.05 . Thus, mobile phones, internet and credit card exercise significant influence on consumer satisfaction. The Enter method regression analysis showed that $53.4 \%$ of the variation in consumer satisfaction can be explained by credit card, internet and mobile phones.

Table 2: Exploratory Factor Analysis Results

\begin{tabular}{ccccc}
\hline Variables & $\begin{array}{c}\text { Mobile } \\
\text { Banking }\end{array}$ & Internet & Credit Cards & $\begin{array}{c}\text { Customer } \\
\text { Satisfaction }\end{array}$ \\
\hline $\begin{array}{c}\text { Cronbach } \\
\text { Alpha }\end{array}$ & 0.821 & 0.816 & 0.834 & 0.828 \\
\hline A1 & 0.512 & & & \\
A2 & 0.467 & & & \\
A3 & 0.536 & & & \\
A4 & 0.742 & & & \\
A5 & 0.635 & & & \\
A6 & 0.271 & 0.184 & & \\
B1 & & 0.664 & & \\
B2 & & 0.138 & & \\
B3 & & 0.618 & & \\
B4 & & 0.607 & & \\
B5 & 0.605 & & \\
B6 & & 0.624 & & \\
B7 & & 0.562 & & \\
B8 & & 0.535 & & \\
B9 & & & & \\
C1 & & & \\
C2 & & & \\
C3 & & & & \\
C4 & & & 0.314 & \\
C5 & & & 0.7054 & \\
\end{tabular}




\begin{tabular}{lll} 
C6 & 0.713 & \\
C7 & 0.658 & \\
\hline D1 & & 0.631 \\
D2 & 0.679 \\
D3 & 0.623 \\
D4 & 0.717 \\
D5 & 0.480 \\
D6 & 0.614 \\
D7 & 0.425 \\
D8 & 0.385 \\
\hline
\end{tabular}

The p-value from the ANOVA was significant (less than 0.001 ) so the independent variables were used to model Consumer Satisfaction Regression analysis showed that for every unit increase in mobile phones, consumer satisfaction was increased by 0.266 units, provided the other variables remained unchanged. Similarly, for every unit increase in internet, consumer satisfaction increased by 0.384 units, provided the other variables. were constant. Moreover, consumer satisfaction increased by 0.315 units for every unit increase in credit card. Hence, all of the three variables; mobile phones, internet and credit card were significant predictors of customer satisfaction.

Table 3: Regression Model for Customer Satisfaction

\begin{tabular}{|l|c|c|c|c|}
\hline Variables & Coefficients & t-statistics & P-value & VIF \\
\hline (Constant) & .429 & 1.260 & .210 & 1.714 \\
\hline Mobile Phones & .266 & 3.199 & .002 & 1.367 \\
\hline Internet & .384 & 4.644 & .000 & 1.738 \\
\hline Credit Card & .315 & 4.921 & .000 & VIF \\
\hline R-Square & & & 0.534 \\
F-Statistics \\
P-Value (F-Stats)
\end{tabular}

Dependent Variable: Customer Satisfaction

Customer satisfaction is significantly influenced by determinants of e-marketing i.e. internet, credit cards and mobile phones (Laforet \& Li, 2005). The idea of having lowered the facilities of a product, while maintaining the Internet, is not applicable for the commercial banks (Rahman, Tajrin, Hossain, \& Das, 2021). Consumers today begin to think or have an impression if a product is facilitated high or matching the consumers' mobile phones, then it is worth the purchase facilities (Heidarzadeh Hanzaee \& Sadeghi, 2010). Moreover, it can be concluded that the commercial banks must maintain its premium facilities to maintain and garner more market share (Shahrokhi, 2008). Consumers judge the worthiness of the product based on the facilities imposed. If it is cheap, which means that the given facilities do not match consumers' mobile phones, then consumers may resort to not buying the product (Kolodinsky, Hogarth, \& Hilgert, 2004). But if the facilities satisfy the consumers' mobile phones, then there is a customer in the making (Ricard, Rajaobelina, 
Arcand, \& Prom Tep, 2021). Hence, marketers must place great importance in pricing their products.

A product's Internet determines the satisfaction level of a customer (Zhou, Liu, \& Liu, 2021). Internet is something that commercial banks can never overlook (Ujunwa, Ujunwa, Onah, \& Ogundele, 2021). In plain words, customer experiences are derived or are largely influenced by the Internet that they experienced or received from the product they use (Shankar, 2021). Furthermore, consumers, customer satisfaction in particularly (as they are the subjects of this research), look for reliability of the product which determines the satisfaction level (Masud, Kari, Saifullah, \& Mohd Satar, 2021). In addition, the user friendliness of the commercial banks, which is suitable for all age groups, makes it a hassle free tablet (Kidron, 2021). Therefore, commercial banks developers, or any product developers, must place great emphasis on Internet in the entire development cycle. A continuous enhancement is a needed trump card in this sector (Khan, Raza, Shah, \& Qazi, 2021). Moreover, the consumer dynamics, especially customer satisfaction, are constantly and almost rapidly evolving, which makes the definition of Internet from the customer's viewpoint being constantly revolutionized (Karjaluoto, Hurpaul, Shaikh, Ramdhony, \& Glavee-Geo, 2021). Thus, constant end to end research and development must be carried out to meet the changing Internet expectations of the customer.

Credit Card of consumers towards a product chalks the successfulness of a product to a large extent (Sorour, El-Sakhawy, Soobaroyen, \& Shrives, 2020). Consumers' credit card towards a product is via direct experience, coupled with the marketing hype surrounding them; in addition, word of mouth spices it up too (Bag, Islam, \& Aich, 2020) . Basically, consumers' credit card can be molded, if the marketing strategy is managed in a favorable manner (Albashrawi \& Windasari, 2020). Credit card of consumers shape the satisfaction level, due to the fact that the main factors of influence are the emotions and feelings towards the commercial banks (Criado, 2021). Hence, companies wanting to market their products must place great emphasis on emotional intelligence to capture the consumers' minds, which can be achieved by good business practices and corporate social responsibility activities.

Hence, new companies wanting to make their foray into the tablet computing market need to focus more on internet facilities and the consumers' credit card. Above all, the banks must watch their consumers' credit card and maintain their product, Internet and facilities to maintain and expand their market share. In fact, this study has revealed that the higher the facilities of a product, the consumers' satisfaction level becomes higher. Some authors (Kotler \& Armstrong, 1997) stated that in the case of prestige goods, consumers thought higher facilities meant it was a better product. The result is further justified by another study (Dapkevičius \& Melnikas, 2009) which found that increases in the mobile phones caused increased satisfaction due to increases in expectation.

In this study, it is proven that Internet is the major factor that encourages more people to use the commercial banks. Accordingly, there is a relationship between Internet and consumer satisfaction. Moreover, the result is justified with the study (Chan \& Chu, 2001) which found that the product's ability to be free from defect for a long period of time boosts the Internet satisfaction. Credit Card of consumers is a learned preferential behavior. This study explains that there is a relationship between credit card and consumer satisfaction. This is justified with the study (Narteh \& Owusu - Frimpong, 2011) which found that cognitive component, affect component and conative component influences new customers and enables the retention of existing customers.

\section{Limitations and Recommendations for Future Research}

This study is aimed at investigating the determinants of consumer satisfaction on commercial banks among customer satisfaction in 
Libya. Hence, it is bound by its objectives which are formed to focus on the factors affecting consumer satisfaction on commercial banks. The conceptual framework of this study has its limitations as with any other model. Thus, the results and findings are limited to the population and the type of product investigated in this research. In other words, findings reported here for the commercial banks may not be applicable to the other tablet computing devices in the market. Furthermore, this study has both time and cost constraints. Powerful commercial banks applications can be developed that can be installed for free in the commercial banks itself to monitor the users' activity. Moreover, a focus group discussion cum interview could be completed to enable students to express themselves verbally as well. The impact of demographic factors such as culture and income level may be focused as these are students who work and study at the same time. This would result in a comprehensive and in-depth analysis of the determinants of consumer satisfaction on commercial banks among customer satisfaction in Libya. Consequently, the findings will help to improve the commercial banks, not only in terms of facilities; but also Internet and also may increase its usage scope to the mass market. Likewise, improved internet experience could be implemented based on the feedback. This will eventually, give a boost to the online education sector, whilst improving communication. Believe it or not, the commercial banks have the potential to set the trend for social networking.

\section{Conclusion}

This study concludes that e-marketing by mobile phones, internet and credit cards is the major influencer for the customer satisfaction in the Libyan banking industry. For sure, the Libyan banking industry should consider implementation of e-marketing to perform well and compete in the banking industry which is the need of the modern era and most importantly, it will enhance customer satisfaction and retention leading to their profitability and economic gain in Libya despite the political instability. To conclude, it is foreseen that that the results of this study will be useful for policy-makers in Libya who are responsible for the development and flourishing of the banking sector in Libya.

\section{REFERENCES}

[1] Abulgasem, M. A., Janicic, R., LecicCvetkovic, D., Kostic-Stankovic, M., \& Gligorijevic, M. (2013). Quality evaluation of banking services for development of ebanking in Libya. Metalurgia International, 18(5), 135.

[2] Ahmadi Danyali, A. (2018). Factors influencing customers' change of behaviors from online banking to mobile banking in Tejarat Bank, Iran. Journal of Organizational Change Management, 31(6), 1226-1233. doi:10.1108/JOCM-072017-0269

[3] Ahmida, A. A. (2012). Libya, Social Origins of Dictatorship, and the Challenge for Democracy. The Journal of the Middle East and Africa, 3(1), 70-81. doi:10.1080/21520844.2012.666646

[4] Al-Ghaith, W., Sanzogni, L., \& Sandhu, K. (2010). Factors influencing the adoption and usage of online services in Saudi Arabia. The Electronic Journal of Information Systems in Developing Countries, 40(1), 1-32.

[5] Albashrawi, M., \& Windasari, N. A. (2020). Behavioral routes to loyalty across gender on m-banking usage. Review of International Business and Strategy, aheadof-print(ahead-of-print).

doi:10.1108/RIBS-06-2020-0073

[6] Bag, S., Islam, M. A., \& Aich, P. (2020). Behavioral intention of "digital natives" toward adapting the online education system in higher education. Journal of Applied Research in Higher Education, ahead-of-print(ahead-of-print). doi:10.1108/JARHE-08-2020-0278

[7] Bapat, D. (2017). Exploring the antecedents of loyalty in the context of multi-channel banking. International Journal of Bank 
Marketing, $\quad 35(2), \quad$ 174-186. doi:10.1108/IJBM-10-2015-0155

[8] Bhat, S. A., Darzi, M. A., \& Parrey, S. H. (2018). Antecedents of Customer Loyalty in Banking Sector: A Mediational Study. Vikalpa, 43(2), 92-105. doi:10.1177/0256090918774697

[9] Chan, B., \& Chu, L. (2001). Method and system for managing chronic disease and wellness online: Google Patents.

[10] Criado, J. I. (2021). Digital Public Administration in Latin America: Digitalization, Public Innovation, and the Future of Technologies in the Public Sector. In C. Ramos, C. A. Tercedor, \& B. G. Peters (Eds.), The Emerald Handbook of Public Administration in Latin America (pp. 343374): Emerald Publishing Limited.

[11] Dapkevičius, A., \& Melnikas, B. (2009). Influence of price and quality to customer satisfaction: Neuromarketing approach. Mokslas-Lietuvos ateitis/Science-Future of Lithuania, 1(3), 17-20.

[12] Ehtisham-Ul-Mujeeb, Shakil Ahmad, M., \& Rashid, S. (2012). ECRM and customers: a case of Askari Commercial Bank, Pakistan. Business Strategy Series, 13(6), 323-330.

doi:10.1108/17515631211286173

[13] El Talla, S. A., Al Shobaki, M. J., \& AbuNaser, S. S. (2019). Electronic Banking Services from the Point of View of Bank Customers in Palestine.

[14] Endara, Y. M., Ali, A. B., \& Ab Yajid, M. S. (2019). The influence of culture on service quality leading to customer satisfaction and moderation role of type of bank. Journal of Islamic Accounting and Business Research.

[15] Faezy Razi, F., \& Shahabi, V. (2019). Modeling the effect of electronic banking expansion on profitability using neural networks and system dynamics approach. Qualitative Research in Financial Markets, 11(2), 197-210. doi:10.1108/QRFM-112018-0117
[16] Gopalaswamy, A. K., \& Nguyen, D. (2018). The interface between electronic banking and accounting modules. Journal of Advances in Management Research, 15(3), 241-264. doi:10.1108/JAMR-042017-0048

[17] Heidarzadeh Hanzaee, K., \& Sadeghi, T. (2010). Customer satisfaction factors (CSFs) with online banking services in an Islamic country. Journal of Islamic Marketing, 1(3), 249-267. doi:10.1108/17590831011082428

[18] Iranzadeh, S., Bafandeh Zendeh, A. R., Aali, S., \& Garepasha, A. (2020). Relationship dynamics in customer loyalty to online banking services. Journal of Islamic Marketing, ahead-of-print(aheadof-print). doi:10.1108/JIMA-09-2019-0183

[19] Karjaluoto, H., Hurpaul, A., Shaikh, A. A., Ramdhony, D., \& Glavee-Geo, R. (2021). Consumption values and mobile banking services: understanding the urban-rural dichotomy in a developing economy. International Journal of Bank Marketing, ahead-of-print(ahead-of-print). doi:10.1108/IJBM-03-2020-0129

[20] Kato, C. I. (2019). Legal framework challenges to e-banking in Tanzania. PSU Research Review, 3(2), 101-110. doi:10.1108/PRR-06-2018-0016

[21] Katz, R. H., Culler, D. E., Sanders, S., Alspaugh, S., Chen, Y., Dawson-Haggerty, S., . . Shankar, S. (2011). An informationcentric energy infrastructure: The Berkeley view. Sustainable Computing: Informatics and $\quad$ Systems, 1(1), 7-22. doi:https://doi.org/10.1016/j.suscom.2010. 10.001

[22] Khan, K. A., Raza, S. A., Shah, S. M. M., \& Qazi, W. (2021). Student as customer concept: an approach to determine Pakistani students' preferences as customers while studying at private universities. International Journal of Educational Management, ahead-of- 
print(ahead-of-print). doi:10.1108/IJEM04-2019-0138

[23] Khizindar, T. M., Al-Azzam, A., \& Khanfar, I. (2015). An empirical study of factors affecting customer loyalty of telecommunication industry in the kingdom of Saudi Arabia. British Journal of Marketing Studies, 3(5), 98-115.

[24] Khrewesh, A. H. (2011). E-banking adoption model in Palestine.

[25] Kidron, A. (2021). Investigating trust in the Israeli banking system from the reciprocating perspectives of customers and bankers: a mixed methods study. International Journal of Bank Marketing, ahead-of-print(ahead-of-print). doi:10.1108/IJBM-07-2020-0360

[26] Kolodinsky, J. M., Hogarth, J. M., \& Hilgert, M. A. (2004). The adoption of electronic banking technologies by US consumers. International Journal of Bank Marketing, 22(4), 238-259. doi:10.1108/02652320410542536

[27] Kotler, P., \& Armstrong, G. (1997). Principles of marketing Cliffs: NJ: Prentice Hall.

[28] Laforet, S., \& Li, X. (2005). Consumers' attitudes towards online and mobile banking in China. International Journal of Bank Marketing, 23(5), 362-380. doi:10.1108/02652320510629250

[29] Liébana-Cabanillas, F., Rejón-Guardia, F., \& Muñoz-Leiva, F. (2013). The determinants of satisfaction with e-banking. Industrial Management \& Data Systems, 113(5), 750-767. doi:10.1108/02635571311324188

[30] Masud, M. M., Kari, F. B., Saifullah, M. K., \& Mohd Satar, N. (2021). Developing smart community based on information and communication technology: an experience of Kemaman smart community, Malaysia. International Journal of Social Economics, ahead-of-print(ahead-of-print). doi:10.1108/IJSE-05-2020-0325
[31] Mishra, V., \& Singh, V. (2015). Selection of appropriate electronic banking channel alternative. International Journal of Bank Marketing, 33(3), 223-242. doi:10.1108/IJBM-09-2013-0099

[32] Momani, R., \& Magatef, S. (2016). The Impact of Sales Promotion on Purchasing Decision of Children's Meals at Fast Food Restaurants in Jordan (Word Chain Restaurants) An Applied Study from Parents Point of View. International Journal of Finance \& Economics.

[33] Narteh, B. (2013a). Key determinant factors for retail bank switching in Ghana. International Journal of Emerging Markets, 8(4), 409-427. doi:10.1108/IJoEM-012011-0004

[34] Narteh, B. (2013b). Service quality in automated teller machines: an empirical investigation. Managing Service Quality: An International Journal, 23(1), 62-89. doi:10.1108/09604521311287669

[35] Narteh, B., \& Owusu-Frimpong, N. (2011). An analysis of students' knowledge and choice criteria in retail bank selection in sub-Saharan Africa. International Journal of Bank Marketing.

[36] Noman, A. H. M., Gee, C. S., \& Isa, C. R. (2017). Does competition improve financial stability of the banking sector in ASEAN countries? An empirical analysis. PLoS One, 12(5), e0176546. doi:10.1371/journal.pone.0176546

[37] Ofori-Boateng, K., Amoh, J. K., \& Awunyo-Vitor, D. (2020). Customers' awareness and knowledge level of fraudulent acts in electronic banking in Ghana: evidence from a universal bank. Journal of Financial Crime, ahead-ofprint(ahead-of-print). doi:10.1108/JFC-082020-0161

[38] Ofori, K. S., Boateng, H., Okoe, A. F., \& Gvozdanovic, I. (2017). Examining customers' continuance intentions towards internet banking usage. Marketing 
Intelligence \& Planning, 35(6), 756-773. doi:10.1108/MIP-11-2016-0214

[39] Osifo, S. J., Eze, S. C., Akintimehin, O., Inegbedion, E. E., Inegbedion, H., \& Ayeni, A. (2019). Exposure to and usage of ebanking channels. Journal of Science and Technology Policy Management, 11(2), 133-148. doi:10.1108/JSTPM-02-20190024

[40] Rahman, M. S., Tajrin, T., Hossain, G. M. S., \& Das, S. (2021). Teenagers' behavioural intention towards wearable technologies and intention to recommend others: an empirical study in Bangladesh. Journal of Science and Technology Policy Management, ahead-of-print(ahead-ofprint). doi:10.1108/JSTPM-05-2020-0088

[41] Ramadan, R., \& Aita, J. (2018). A model of mobile payment usage among Arab consumers. International Journal of Bank Marketing, 36(7), 1213-1234. doi:10.1108/IJBM-05-2017-0080

[42] Ricard, L., Rajaobelina, L., Arcand, M., \& Prom Tep, S. (2021). The relationship of brand attachment and mobile banking service quality with positive word-ofmouth. Journal of Product \& Brand Management, ahead-of-print(ahead-ofprint). doi:10.1108/JPBM-02-2020-2747

[43] Rios, R. E., \& Riquelme, H. E. (2010). The moderating effect of gender in the adoption of mobile banking. International Journal of Bank Marketing, 28(5), 328-341. doi:10.1108/02652321011064872

[44] Sampaio, C. H., Perin, M. G., Dolci, P. C., Santini, F. D. O., \& Ladeira, W. J. (2019). A meta-analytical study of technological acceptance in banking contexts. International Journal of Bank Marketing, 37(3), 755-774. doi:10.1108/IJBM-042018-0110

[45] Sandhu, S., \& Arora, S. (2018). Usage based upon reasons: the case of electronic banking services in India. International Journal of Bank Marketing, 36(4), 680-700. doi:10.1108/IJBM-03-2017-0060
[46] Sandoval, A. V., Canada, F.-J. A., SánchezTorres, J. A., \& Alzate, J.-A. S. (2018). Ebanking in Colombia: factors favouring its acceptance, online trust and government support. International Journal of Bank Marketing, 36(1), 170-183. doi:10.1108/IJBM-10-2016-0145

[47] Shahrokhi, M. (2008). E-finance: status, innovations, resources and future challenges. Managerial Finance, 34(6), 365-398. doi:10.1108/03074350810872787

[48] Shankar, A. (2021). How does convenience drive consumers' webrooming intention? International Journal of Bank Marketing, ahead-of-print(ahead-of-print). doi:10.1108/IJBM-03-2020-0143

[49] Sorour, M. K., El-Sakhawy, A. A., Soobaroyen, T., \& Shrives, P. J. (2020). Exploring the evolving motives underlying corporate social responsibility (CSR) disclosures in developing countries: the case of "political CSR" reporting. Accounting, Auditing \& Accountability Journal, ahead-of-print(ahead-of-print). doi:10.1108/AAAJ-07-2019-4080

[50] Susanto, A., Chang, Y., \& Ha, Y. (2016). Determinants of continuance intention to use the smartphone banking services. Industrial Management \& Data Systems, 116(3), 508-525. doi:10.1108/IMDS-052015-0195

[51] Ujunwa, A., Ujunwa, A. I., Onah, E. O., \& Ogundele, O. S. (2021). Effect of financial technology on cash holding in Nigeria. African Journal of Economic and Management Studies, ahead-ofprint(ahead-of-print). doi:10.1108/AJEMS04-2020-0190

[52] Umer, A., Dahri, A. S., Raza, S. A., \& Qureshi, M. A. (2020). Internet banking service quality, e-customer satisfaction and loyalty: the modified e-SERVQUAL model. The TQM Journal, 32(6), 14431466. doi:10.1108/TQM-02-2020-0019 
[53] Zhou, M., Liu, Y., \& Liu, C. (2021). Does digital inclusive finance promote agricultural production for rural households in China? Research based on the Chinese family database (CFD). China Agricultural Economic Review, ahead-of-print(aheadof-print). doi:10.1108/CAER-06-20200141 